\title{
Случайная непрерывная генерация каскадного ВКР-лазера в градиентном световоде с многомодовой диодной накачкой
}

\author{
Е.А. Евменова ${ }^{1}$, С.И. Каблуков ${ }^{1,2, *}$, А.Г. Кузнецов ${ }^{1}$, И.Н. Немов ${ }^{1}$, \\ А.А. Воль ${ }^{1,2}$, А.В. Достовалов ${ }^{1,2}$, С.А. Бабин ${ }^{1,2}$ \\ ${ }^{1}$ Институт автоматики и электрометрии СО РАН \\ ${ }^{2}$ Новосибирский государственный университет \\ *E-mail: kab@iae.nsk.su
}

DOI:10.31868/RFL2018.76-77

Волоконные ВКР-лазеры со случайной распределённой обратной связью (СРОС) на рэлеевском рассеянии были открыты относительно недавно и благодаря простоте конструкции привлекли к себе внимание большого количества исследователей [1]. В случае каскадной ВКР-генерации в лазерах со СРОС эффективность оказывается выше, чем в ВКР-лазерах с вложенными резонаторами на волоконных брэгговских решётках (ВБР) [2]. Увеличение эффективности объясняется специфическим распределением генерируемого излучения и отсутствием потерь на зеркалах, так как широкополосное кольцевое зеркало и рэлеевская обратная связь обеспечивают генерацию промежуточных и выходного стоксовых порядков в отсутствие ВБР. Значительный интерес также вызывают мощные ВКР-лазеры работающие на многомодовых световодах с градиентным профилем показателя преломления [3]. Специфика таких световодов позволяет, с одной стороны, эффективно заводить в них излучение многомодовых (ММ) лазерных диодов (ЛД), а с другой стороны генерировать стоксово излучение с высоким качеством пучка. Так при использовании градиентных световодов с диаметром сердцевины 100 мкм получено более 60 ВТ стоксова излучения на длине волны 954 нм с качеством пучка $\mathrm{M}^{2} \sim 3.2$ в полностью волоконной конфигурации генерации ВКР-излучения с заведением излучения накачки ММ ЛД (915 нм) через волоконный объединитель накачек [3]. В ВКР-лазере с более мощными ЛД с высокой яркостью получено 154 ВТ излучения на длине волны 1020 нм с качеством пучка $\mathrm{M}^{2} \sim 8$, но в резонаторе с использованием объёмных элементов [4]. Стоит отметить, что, с одной стороны, мощность генерации в таких лазерах зачастую ограничена появлением случайной генерации стоксова излучения 2-го порядка, a, с другой стороны, ВКР-генерация 1-го порядка со СРОС при накачке многомодовыми диодами была ограничена уровнем мощности до 1 Вт. В представляемой работе мы использовали конфигурацию полуоткрытого резонатора [1,2] для генерации второй стоксовой компоненты, в которой с одной стороны лазера установлена ВБР для селекции генерируемой длины волны, а слабая СРОС на рэлеевском рассеянии возникает на всём протяжении световода. Благодаря высокой мощности и качеству пучка излучения, генерируемого в ВКР-лазере с линейным резонатором для первой стоксовой компоненты, удаётся получить высокую мощность в лазере со СРОС, генерирующем на второй стоксовой компоненте.

Схема эксперимента аналогична, описанной в [5] (Рис. 1). В качестве активной среды лазера использовался градиентный световод длиной 1.1 км с диаметром сердцевины 100 мкм. При этом на выход волоконного объединителя накачек перед резонатором волоконного ВКР-лазера на первую стоксову компоненту с волоконными зеркалами ВБР с1 (плотная ВБР записана УФ 


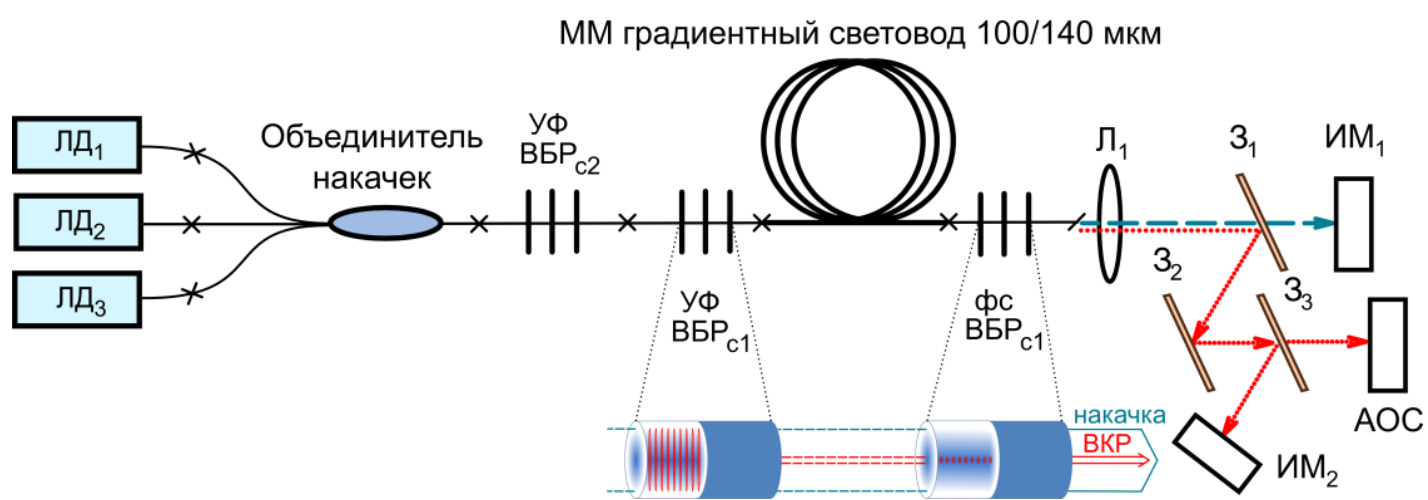

Рис. 1. Схема каскадного ВКР-лазера со СРОС для второй стоксовой компоненты.

излучением, а выходная - фемтосекундным ИК излучением) устанавливалась дополнительная $\mathrm{BБР}_{\mathrm{c} 2}(У Ф)$ на длину волны второй стоксовой компоненты для создания ВКР-лазера со СРОС с полуоткрытым резонатором. Длина волны ВБР 2 лазера со СРОС варьировалась в пределах от 978 до 996 нм, а стоксов сдвиг от 300 до $486 \mathrm{~cm}^{-1}$ соответственно. Длина волны 978 нм перспективна для накачки твердотельных лазеров, на ней получена выходная мощность $\sim 17$ Вт. В максимуме ВКР-усиления (996 нм) мощность второй стоксовой компоненты составила 27 Вт. Качество пучка ВКР-лазера на брэгговских решётках для первой стоксовой компоненты было относительно высоким $\mathrm{M}^{2} \sim 2.3$ в сравнении с качеством пучка многомодовой диодной накачки $\left(\mathrm{M}^{2}>30\right)$, измеренном на выходе объединителя накачек, а при генерации второй стоксовой компоненты в лазере со СРОС качество ещё улучшалось - до $\mathrm{M}^{2} \sim 1.6$.

В докладе будут описаны результаты экспериментов и проведено сравнение генерации второй стоксовой компоненты в ВКР-лазерах с линейным резонатором на двух ВБР и с полуоткрытым резонатором со СРОС.

Исследования поддержаны Российским научным фондом (проект № 14-22-00118).

\section{Литература}

[1] S.K. Turitsyn et al. Phys. Rep., 542, 133-193 (2014).

[2] S.A. Babin et al. Sci. Rep., 6, 22625 (2016).

[3] S.A. Babin et al. IEEE J. Sel. Top. Quantum Electron. 24, 1400310 (2018).

[4] Y. Glick et al. Appl. Opt. 56, B97-B102 (2017).

[5] E.A. Evmenova et al. Laser Phys. Lett. 15, 095101 (2018) 